\title{
Using Cucumis sativus, Acalymma vittatum, Celatoria setosa, and generalist pollinators as a case study for plant-insect interactions
}

\author{
Matthew R. Barrett ${ }^{1}$ (D) . Camila C. Filgueiras ${ }^{1}$ (D) . Denis S. Willett ${ }^{1}$ (D
}

Received: 19 January 2021 / Accepted: 19 June 2021 / Published online: 13 July 2021

(c) The Author(s) 2021

\begin{abstract}
Showcasing how semiochemicals are both multifunctional and can influence a community of organisms is a constant frontier shared by chemical ecologists and applied entomologists alike. As researchers in these fields continue to share broad and overlapping interests, converging on one system could allow for a better understanding of community interactions and the chemical substances that mediate them. Cucurbit systems are strategically positioned to study these types of interactions because they combine the elements of plant-herbivore, plant-predator, and plant pollinator into one model and are systems where researchers can pursue both basic and applied questions. In this review, we propose Cucumis sativus [cucumber], Acalymma vittatum [striped cucumber beetle], Celatoria setosa [a natural enemy], and generalist pollinators as a system for continued investigation into semiochemicals, their multifunctional roles, and their influence on both target and nontarget organisms. We believe this system is ripe for further exploration at the frontiers in chemical ecology and applied entomology.
\end{abstract}

Keywords Cucumis sativus $\cdot$ Acalymma vittatum $\cdot$ Celatoria setosa $\cdot$ Semiochemicals $\cdot$ Chemical ecology $\cdot$ Multitrophic interactions

\section{Introduction: Why coalesce on a system?}

Plants, insects, and their natural enemies account for an abundance of diverse and ecologically important interactions. Driving these interactions are semiochemicals-substances that provide the framework for cross-taxa communication and behavior. Despite these abundant and diverse interactions, some substances are repeatedly used as an important chemical signal between and across multiple organisms (Raguso 2016). Investigating how semiochemicals have wide effects and influence a community of organisms, including target and nontarget receivers, have remained of interest especially against the backdrop of agroecosystems (Theis et al. 2009; Mallinger et al. 2011; Barber et al. 2012;

Handling Editor: Ingeborg Menzler-Hokkanen.

Matthew R. Barrett

mb2657@cornell.edu

Camila C. Filgueiras

camilafilguerias@cornell.edu

Denis S. Willett

deniswillett@cornell.edu

1 Cornell AgriTech, Cornell University, Geneva, NY, USA
Shapiro et al. 2012; Theis and Adler 2012; Theis et al. 2014; Reviewed in Raguso et al. 2015; Brzozowski et al. 2016; Filgueiras et al. 2016; Davis et al. 2019; Helms et al. 2019; Brzozowski et al. 2020). And since many chemical ecologists and applied entomologist share broad and overlapping interests coalescing on one system could allow for a deeper understanding of plant-insect interactions, especially if that system could combine the elements of plant-herbivore, plant-predator, and plant-pollinator interactions into one. Cucurbit systems are strategically positioned to study plant-insect interactions and the semiochemicals that influence them. Cucurbits are diverse and grown across the globe (Chomicki et al. 2020), require insect pollination (McGregor 1976), are subjected to diverse above- and below-ground herbivory (Mondal et al. 2020), suffer insect vectored pathogens (Review in Rojas et al. 2015), recruit natural enemies (Agrawal et al. 2002; Grunseich et al. 2020), and produce unique secondary defense compounds (Metcalf et al. 1980). In this review, we propose Cucumis sativus [cucumber], Acalymma vittatum [striped cucumber beetle], Celatoria setosa [a natural enemy], and generalist pollinators as such a system. Our goal in this review is to showcase that this proposed system is interesting and eminently useful in 
pursuing frontier questions in chemical ecology and applied entomology.

\section{The system: a brief overview}

We believe Cucumis sativus [cucumber], Acalymma vittatum [striped cucumber beetle], Celatoria setosa [a natural enemy], and generalist pollinators when combined are an interesting model system for exploring the boundaries in chemical ecology and applied entomology (Fig. 1).

Cucumbers (Cucumis sativus) are a widely grown and economically important annual crop (Chomicki et al. 2020) pollinated by Apis mellifera [honey bees] and various species of bumblebees, such as Bombus impatiens (Stanghellini et al. 2002a, b). Cucumbers have also been repeatedly been used to pursue frontiers in chemical ecology, such as investigating chemical defenses and the recruitment of natural enemies using herbivore-induced plant volatiles (HIPVs) (Da Costa and Jones 1971; Howe et al. 1972; Gould and Massey 1984; Takabayashi 1994a, b; Agrawal et al. 1999; Agrawal et al. 2002; Balkema-Boomstra et al. 2003; Kappers et al. 2011; Grunseich et al. 2020) or links between above- and below-ground processes (Barber et al. 2011, 2012). In addition, the genome of C. sativus was also completed in 2009 (Huang et al. 2009) paving the way for future research with genetic applications, such as novel gene discovery (Shang et al. 2014), important signaling molecules in induced responses (Liu et al. 2019), transcriptome adaptations in response to herbivory (He et al. 2020), and insights into diversification of cucurbit lineages (Qi et al. 2013; Chomicki et al. 2020).

Acalymma vittatum [striped cucumber beetle] (SCB) is a specialist herbivore and major pest of all cucurbits including C. sativus (Ellers-Kirk and Fleischer 2006). SCB are highly destructive pests that feed above- and below-ground in larval and adult stages, respectively, use an aggregation pheromone (vittatalactone) to increase congregation onto their host plant (Smyth and Hoffmann 2003; Morris et al. 2005), and can phytophagously vector Erwinia tracheiphila, the pathogen cause of bacterial wilt (Reviewed in Rojas et al 2015). SCB are obligate herbivores to cucurbits and as a consequence their behavior and biology are strongly influenced by cucurbit chemistry including secondary defense metabolites, blossom volatiles, and foliar volatiles (Metcalf et al. 1980; Lewis et al. 1990; Metcalf et al. 1995; Andrews et al. 2007; Shapiro et al. 2012; Theis et al. 2014; Brzozowski et al. 2020).

Celatoria setosa (Colliquet) [Diptera: Tachinidae] is a small and elusive parasitoid fly that is perhaps the best above ground natural enemy of SCB. Celatoria setosa has been found in in Illinois, Maryland, and New York, Ohio, and Pennsylvania and has been shown capable of parasitizing nearly half the wild SCB population (Walton 1914; Houser and Balduf 1925; Bussart 1937; Fischer 1983; Smyth and Hoffmann 2010; Coco et al. 2020). When combined these organisms create a unique model system that can be used for all fronts of plant-insect interactions. Although some of these organisms have also been extensively researched like $C$. sativus, other organisms like Celatoria setosa remain largely unexplored and provide new and exciting opportunities to investigate the influence of semiochemicals and their multifunctional nature.

\section{Semiochemicals in the system}

In this section, we highlight important characteristics of our proposed system and why it is a useful model for continued investigations of plant-insect interactions and the multifunctional nature of semiochemicals. We also highlight relevant semiochemicals and their effects and influences on other organisms. Finally, we touch on the recent discoveries within our system and discuss unexplored areas and opportunities for future research.

\section{Toxic terpenoids: chemical defense in C. sativus, kairomones in striped cucumber beetle, and effects on nontarget organisms}

Cucurbits chemically defend themselves against herbivory by producing a class of secondary defense compounds called cucurbitacins. Cucurbitacins are nonvolatile oxygenated tetracyclic triterpenoids that also are highly toxic. Cucurbitacins are well-studied and have a range of adverse effects on organisms that consume them including general cytotoxicity, cell-growth inhibition (Revi, digestive irritation, insect molting disruption, and feeding and oviposition deterrence (Chambliss and Jones 1966; Da Costa and Jones 1971; Reviewed in Jeffery 1980; Metcalf et al. 1980; Stowesand et al. 1985; Metcalf 1986; Tallamy and Gorski 1997; Tallamy et al. 1997; Dinan et al. 1997; Reviewed in Metcalf and Lampman 1989; Agrawal et al. 1999; Tallamy et al. 2000; Agrawal et al. 2002; Balkema-Boomstra et al. 2003). Cucurbitacins also function as an important karimone and phagostimulant in SCB, in both larvae and adults. For example larvae have been shown to grow larger and faster when reared on bitter diets as compared to nonbitter diets (Tallamy and Gorski 1997; Smyth et al. 2002) and adults displays clear preferences for cucurbit varieties that are higher in cucurbitacin concentration (Ferguson and Metcalf 1985; Tallamy and Gorski 1997; Smyth et al. 2002) although these preferences were found to be affected by age, sex, and previous feeding history (Smyth et al. 2002). SCB adults and larvae have also been shown to sequester cucurbitacins in various tissues including hemolymph, elytra, and adipose 
Fig. 1 A graphical representation of our proposed system consisting Cucumis sativus [cucumber], Acalymma vittatum [striped cucumber beetle], Celatoria setosa [a natural enemy], and generalist pollinators with arrows indicating various semiochemicals and their multifunctional interactions within a community of organisms. Solid arrow indicates direct influences of a semiochemical or blend of semiochemicals supported by evidence, whereas dashed arrows indicate suspected semiochemical influence where more research is needed. The lettering "AG" and "BG" represent aboveground or belowground respectively

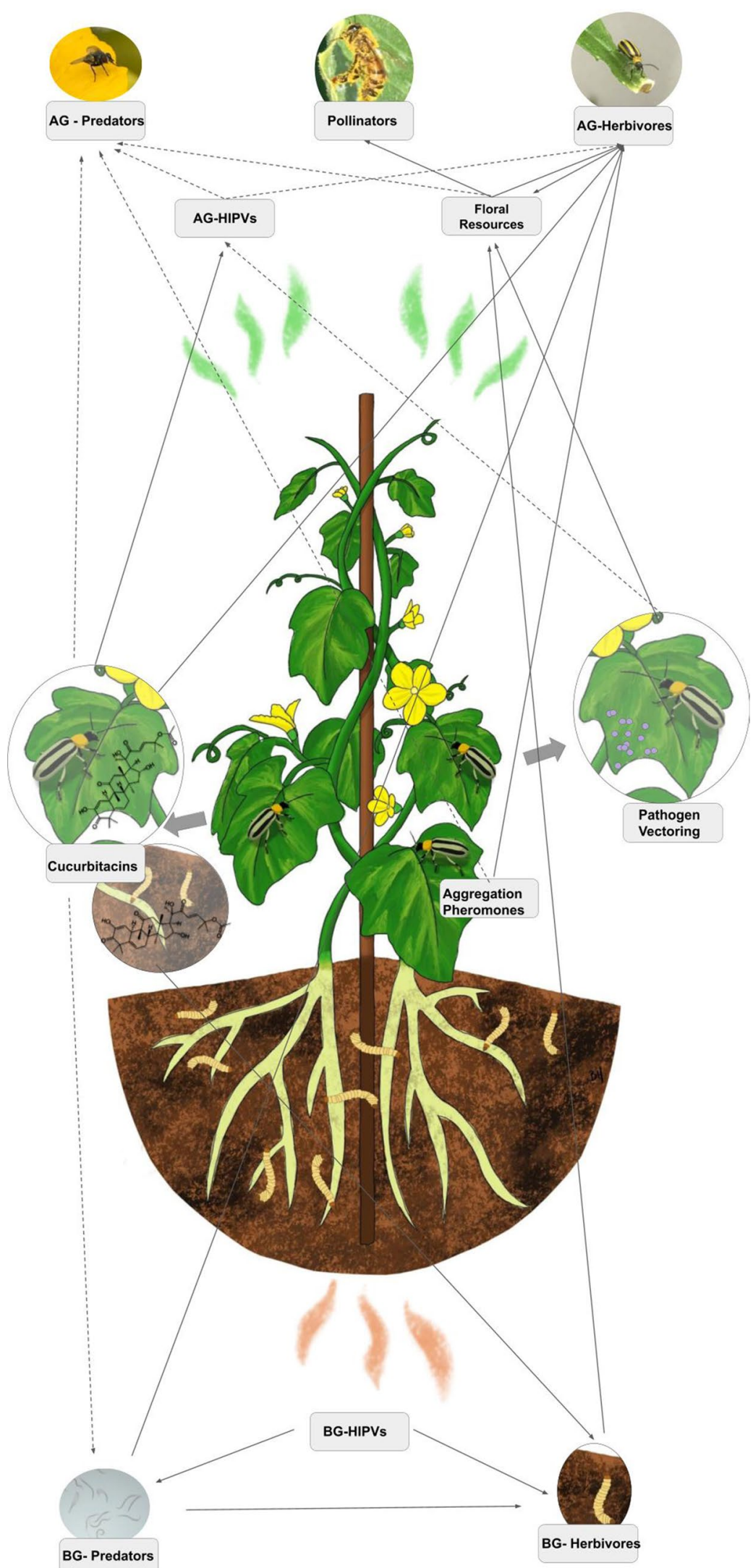


tissue (Ferguson et al. 1983, 1985; Ferguson and Metcalf 1985).

Despite the wealth of knowledge surrounding cucurbitacins in both C. sativus and SCB, there are still a lot of unanswered questions regarding cucurbitacins and the greater role they play in the ecology of SCB and other nontarget organisms that come in contact with cucurbitacins indirectly (Fig. 1). For example, sequestration of these toxic secondary metabolites has been shown to increase defense against some predators (Ferguson and Metcalf 1985), but other natural enemies, such as Celatoria setosa appear largely unaffected. C. setosa has been shown to parasitize really high percentages of SCB (upwards of $57 \%$ of a population sample) (Bussart 1937) and is orders of magnitude smaller than the predator (Tenodera aridifolia sinensis) used by Ferguson and Metcalf in their 1985 experiment. Although no study has directly compared the concentration of cucurbitacins in beetles parasitized by $C$. setosa it would seem that this parasitoid can tolerate some level of concentrations of cucurbitacins. Investigating how these predators deal with a toxic host would provide new insight into our understanding of indirect effects of plant defenses and the broader effects of cucurbitacins on beneficial organisms.

In a similar scenario, it is very likely that the pathogen vectored by SCB, Erwinia tracheiphila, is also coming into contact with dietary cucurbitacins. Populations of SCB have been shown to become increasingly infected with Erwinia tracheiphila throughout the growing season (Brust 1997 and Erwinia tracheiphila cells have been shown to adhereto and persist-in SCB digestive tracts for as long as 30 days (Garcia-Salazar et al. 2000). As populations of SCB consume and metabolize cucurbitacins, Erwinia tracheiphila cells in infected SCB beetles are likely coming come into contact with cucurbitacins. It is not known if this association between SCB and Erwinia tracheiphila is mutualistic or parasitic, but it does present an interesting opportunity to use $C$. sativus and $A$. vittatum to investigate interactions of cucurbitacins with an agriculturally important pathogen, Erwinia tracheiphila. Microbial chemical ecology is already an emerging frontier (Reviewed in Schmidt et al. 2019) and any interaction would be evidence of chemically mediated tri-trophic relationship. It may be possible that Erwinia tracheiphila is more parasitic in nature to SCB, and that SCB feeds on cucurbitacins to self-medicate against an infection. Self-medication behavior by consuming plant secondary metabolites has been shown in other systems including beetles Drosophila to (Milan et al. 2012) and Lepidopterans (Singer et al. 2009; Povey et al. 2014) to defend against parasitism but used against a pathogen is relatively novel.

\section{Cucumis sativus recruits natural enemies above- and belowground}

When plants are damaged by herbivores, they release specific volatile organic compounds, commonly referred to as herbivore-induced-plant volatiles or (HIPVs), and these substances have been thoroughly studied across multiple systems (Reviewed in Turlings and Erb 2018). HIPVs can also serve as important chemical cues mediating plant insect interactions, such as priming plant defenses (Thaler 1999; Yi et al. 2009; Helms et al. 2019), deterring subsequent herbivory (Kessler and Baldwin 2001; Mallinger et al. 2011; Grunseich et al. 2020) or recruiting natural enemies (Kessler and Baldwin 2001; Kappers et al. 2011; Mallinger et al. 2011; Grunseich et al. 2020).

Aboveground, $C$. sativus has been shown to release HIPVs that help recruit natural enemies. For example $C$. sativus leaves were found to release four terpenes (E)- $\beta$ ocimene, (3E)-4,8-dimethyl-1,3,7-nonatriene, (E,E)-TMTT, and $(\mathrm{E}, \mathrm{E})-\alpha$-farnesene, as well as methyl salicylate when attacked by spider mites (Takabyashi et al. 1994a, b; Agrawal et al. 2002; Kappers et al. 2011). Damaged C. sativus plants were also found to be highly attractive to predatory mites and other insect herbivores (Agrawal et al. 2002; Kappers et al. 2011) and highlight a classic example of the semiochemical multifunctionality in which spider mite natural enemies using HIPVs as a karimonal cue. In addition, some of these compounds have been shown to recruit natural enemies in other systems such as (E)- $\beta$-ocimene and (3E)-4,8-dimethyl-1,3,7-nonatriene recruiting insect herbivore predators in cotton (Röse et al. 1998) and methyl salicylate recruiting predators in soybeans (Mallinger et al. 2011). In addition, a study published in 2012 found that $C$. pepo texana infected with $E$. tracheiphila released a blend of volatile compounds including terpenes like ocimene and nonatriene that were found to attract SCB adults (Shapiro et al. 2012). Specific and blended HIPVs from damaged cucurbit foliage likely function as an important cue for SCB host selection as well but more research is needed to fully understand this relationship.

Cucumbers also can release HIPVs belowground. In a recent study investigating belowground HIPVs in response to SCB larva feeding on $C$. sativus seedings, researchers found that $C$. sativus seedings released three monoterpenes [camphene, $\alpha$-pinene, and sabinene] (Grunseich et al 2020). Seedlings that were damaged were more attractive to entomopathogenic nematodes, suggesting that $C$. sativus recruits below ground predators too (Grunseich et al 2020). In addition, SCB larva display preference for undamaged seedlings as compared to damaged seedlings that suggests these belowground HIPVs could also function as a subsequent herbivore deterrent or cue that predators are nearby. No study has looked at specific foliar HIPVs in response to 
SCB herbivory, nor attractiveness of SCB damaged foliage to aboveground natural enemies such Celatoria setosa. Similar to recruitment of other predators it is likely that C. setosa uses $C$. sativus HPIVs as cue, but more research would be needed to determine which compound or blends of compounds are attractive.

\section{Interactions between pollinators and herbivores and possible chemical cues}

Researchers have used different combinations of cucurbit varieties, herbivores and pollinators to investigate multitrophic interactions. Discussing all of them beyond the scope of this piece, but two studies have used this proposed system (Barber et al. 2011, 2012) to investigate possible links between above- and below-ground processes with herbivores and pollinators. In one of these experiments researchers investigated the effects of above- and below-ground SCB herbivory on subsequent herbivory as well as flower production, floral resources, and pollination in $C$. sativus (Baber et al. 2011). The researchers found that honeybees spent more time probing $C$. sativus flowers on plants with root damage with less time spent probing plants with leaf damage (Barber et al 2011). They also found that $C$. sativus plants with root herbivory produced fewer female flowers and had limited pollen production (Barber et al. 2011). In a similar study published a year later researchers found that SCB herbivory reduced honey bee and bumble bee visitations (Barber et al, 2012). Researchers also noticed the SCB were also less attracted to $C$. sativus with previous damage (Barber et al. 2012). Cucumbers typically produce more male flowers than female flowers and allocate more nectar to female flowers than male flowers (Collison 1973) so it is interesting that honeybees spend more time probing flowers with enhanced root damage but less time in flowers with leaf damage in Barber et al. 2011 experiments. Although the blend and ratio of volatiles can often be more important than the individual volatiles released (Reviewed in Raguso et al. 2015), it has been shown that cucumbers roots when damaged by SCB larva release the monoterpene $\alpha$-pinene. $\alpha$-pinene was also found to be a principal volatile compound released in cucumber flowers (Barber et al. 2012). Belowground volatile blends that contained $\alpha$-pinene were also found to deter subsequent SCB larva herbivory as well as attract entomopathogenic nematodes (Grunseich et al 2020). It is possible that both SCB and pollinating bees use $\alpha$-pinene as an important chemical cue given that it is release by both roots and flowers but more research is needed to better understand this relationship.

In addition to $\alpha$-pinene, $C$. sativus flowers have also been found to release other major floral fragrances including benzaldehyde, benzyl alcohol, 1,2-dimethoxybenzene, $\alpha$-farnesene, and perhaps most relevant, linalool and its metabolites (Barber et al. 2012; Wei et al. 2016). Linalool is a classic semiochemical found is many plant-pollinator and plant-herbivore systems and has a wide range of effects (Reviewed in Raguso 2016) wide range of effects further emphasizing how some semiochemicals have a diverse ra. In C. sativus flowers, linalool serves as cue for pollinators (Barber et al. 2012) but the timing and concentration of released linalool and its metabolites may be more important for pollinators and perhaps herbivores too like SCB that are attracted as well. In fact, a recent study using $P$. digitalis and bumble bees, researchers showed under laboratory conditions only that bumble bees were able to discriminate among concentrations of linool (Burdon et al. 2020). More work however is needed to better under the relationship of pollinator signal discrimination and perhaps $C$. sativus and bumble bees would be a good model system to use. $C$. sativus flowers already allocate resources based on sex, such as female flowers producing significantly more nectar than male flowers (Collison 1973) and a recent study from 2016 showed that male and female flowers produce very different volatiles profiles (Wei et al. 2016).

\section{Final remarks}

Cucumis sativus, Acalymma vittatum, Celatoria setosa, and generalist pollinators comprise a unique study system for chemical ecology that showcase how semiochemicals are both multifunctional and can influence a community of organisms. C. sativus, like other cucurbits, synthesizes extremely bitter triterpenoid compounds known as cucurbitacins. These compounds have shown to be effective chemical defenses for cucurbits and are also exploited by cucurbit specialist beetles as kairomones that provide important cues for their biology and behavior. Cucumbers also release blends of terpenes and other volatiles when under attack by herbivores that have been shown to recruit natural enemies above and belowground as well as deterring subsequent herbivory. The manner in which cucurbitacins mediate the interactions with predators and pathogens is a frontier both for this system and for chemical ecology in general. This is especially the case for investigations into the ecology of Celatoria setosa. In addition, using this model system to investigate above- and belowground multitrophic interactions remain an area for further exploration. The dynamic interactions between cucurbits, their herbivores, and their pollinators could piece together an entire story of chemically mediated interactions across a breadth of interactions.

Author contributions MRB, CCF, and DSW contributed to the conception and writing of this work. 


\section{Declarations}

Conflict of interest The authors listed below certify that they have no affiliation or involvement in any organization, individual, or entity with any financial interest or non-financial interest in the subject matter or materials discussed in this manuscript. Text adopted by Elsevier https://doi.org/10.1016/j.asjsur.2011.11.003.

Open Access This article is licensed under a Creative Commons Attribution 4.0 International License, which permits use, sharing, adaptation, distribution and reproduction in any medium or format, as long as you give appropriate credit to the original author(s) and the source, provide a link to the Creative Commons licence, and indicate if changes were made. The images or other third party material in this article are included in the article's Creative Commons licence, unless indicated otherwise in a credit line to the material. If material is not included in the article's Creative Commons licence and your intended use is not permitted by statutory regulation or exceeds the permitted use, you will need to obtain permission directly from the copyright holder. To view a copy of this licence, visit http://creativecommons.org/licenses/by/4.0/.

\section{References}

Agrawal AA, Gorski PM, Tallamy DW (1999) Polymorphism in plant defense against herbivory: constitutive and induced resistance in Cucumis sativus. J Chem Ecol 25:2285-2304. https://doi.org/10. 1023/A:1020821823794

Agrawal AA, Janssen A, Bruin J, Posthumus MA, Sabelis MW (2002) An ecological cost of plant defence: attractiveness of bitter cucumber plants to natural enemies of herbivores. Ecol Lett 5:377-385. https://doi.org/10.1046/j.1461-0248.2002.00325.x

Andrews ES, Theis N, Adler LS (2007) Pollinator and herbivore attraction to cucurbita floral volatiles. J Chem Ecol 33:1682-1691. https://doi.org/10.1007/s10886-007-9337-7

Balkema-Boomstra AG, Zijlstra S, Verstappen FWA, Inggamer H, Mercke PE, Jongsma MA, Bouwmeester HJ (2003) Role of cucurbitacin $\mathrm{C}$ in resistance. J Chem Ecol 29:225-235. https://doi.org/10. 1023/A:1021945101308

Barber NA, Adler LS, Bernardo HL (2011) Effects of above- and belowground herbivory on growth, pollination, and reproduction in cucumber. Oecologia 165:377-386. https://doi.org/10.1007/ s00442-010-1779.x

Barber NA, Adler LS, Theis N, Hazzard RV, Kiers ET (2012) Herbivory reduces plant interactions with above- and belowground antagonists and mutualists. Ecology 93:1560-1570. https://doi. org/10.1890/11-1691.1

Brust GE (1997) Seasonal variation in percentage of striped cucumber beetles (Coleoptera: Chrysomelidae) that vector Erwinia tracheiphila. Environ Entomol 26:580-584. https://doi.org/10.1093/ ee/26.3.580

Brzozowski L, Gardner J, Hoffmann MP, Kessler A, Agrawal AA, Mazourek M (2020) Attack and aggregation of a major squash pest: parsing the role of plant chemistry and beetle pheromones across spatial scales. J Appl Ecol 57:1442-1451. https://doi.org/ 10.1111/1365-2664.13689

Burdon RCF, Raguso RA, Gegear RJ, Pierce EC, Kessler A, Parachnowitsch AL (2020) Scented nectar and the challenge of measuring honest signals in pollination. J Ecol 108(5):2132-2144. https://doi.org/10.1111/1365-2745.13432

Bussart JE (1937) The bionomics of Chaetophleps Setosa Coquillett (Diptera: Tachinidae). Ann Entomol Soc Am 30:285-295. https:// doi.org/10.1093/aesa/30.2.285
Chambliss OL, Jones CM (1966) Cucurbitacins: specific insect attractants in Cucurbitaceae. Science 153:1392-1393. https://doi.org/10. 1126/science.153.3742.1392

Chomicki G, Schaefer H, Renner SS (2020) Origin and domestication of Cucurbitaceae crops: insights from phylogenies, genomics and archaeology. New Phytol 226:1240-1255. https://doi.org/10.1111/ nph. 16015

Coco AM, Lewis MT, Fleischer SJ, Tooker JF (2020) Parasitoids, nematodes, and protists in populations of striped cucumber beetle (Coleoptera: Chrysomelidae). Environ Entomol 49:13161326. https://doi.org/10.1093/ee/nvaa116

Collison CH (1973) Nectar secretion and how it affects the activity of honey bees in the pollination of hybrid pickling cucumbers, Cucumis sativus L. MSc Thesis, Michigan State University

Da Costa CP, Jones CM (1971) Cucumber beetle resistance and mite susceptibility controlled by the bitter gene in Cucumis sativus L. Science 172:1145-1146. https://doi.org/10.1126/science.172. 3988.1145

Davis JK, Aguirre LA, Barber NA, Stevenson PC, Adler LS (2019) From plant fungi to bee parasites: Mycorrhizae and soil nutrients shape floral chemistry and bee pathogens. Ecology 100:e2801. https://doi.org/10.1002/ecy.2801

Dinan L, Whiting P, Girault JP, Lafont R, Dhadialla TS, Cress DE, Mugat B, Antoniewski C, Lepesant JA (1997) Cucurbitacins are insect steroid hormone antagonists acting at the ecdysteroid receptor. Biochem J 327:643-650. https://doi.org/10.1042/ bj3270643

Ellers-Kirk C, Fleischer SJ (2006) Development and life table of Acalymma vittatum (Coleoptera: Chrysomelidae), a vector of Erwinia tracheiphila in cucurbits. Environ Entomol 35:875-880. https:// doi.org/10.1603/0046-225X-35.4.875

Ferguson JE, Metcalf RL (1985) Cucurbitacins: Plant-derived defense compounds for diabroticites (Coleoptera: Chrysomelidae). J Chem Ecol 11:11-318. https://doi.org/10.1007/BF01411417

Ferguson JE, Metcalf ER, Metcalf RL, Rhodes AM (1983) Influence of cucurbitacin content in cotyledons of Cucurbitaceae cultivars upon feeding behavior of Diabroticina beetles (Coleoptera: Chrysomelidae). J Econ Entomol 76(1):47-51. https://doi.org/10. 1093/jee/76.1.47

Ferguson JE, Metcalf RL, Fischer DC (1985) Disposition and fate of cucurbitacin B in five species of diabroticites. J Chem Ecol 11:1307-1321. https://doi.org/10.1007/BF01024118

Filgueiras CC, Willett DS, Pereira RV, Moino Junior A, Pareja M, Duncan LW (2016) Eliciting maize defense pathways aboveground attracts belowground biocontrol agents. Sci Rep 6(1):36484. https://doi.org/10.1038/srep36484

Fischer DC (1983) Celatoria diabroticae Shimer and Celatoria setosa Coquillett: Tachinid parasitoids of the diabroticite Coleoptera. Dissertation, Univ Illinois at Urbana-Champaign

Garcia-Salazar C, Gildow FE, Fleischer SJ, Cox-Foster D, Lukezic FL (2000) Elisa versus immunolocalization to determine the association of Erwinia tracheiphila in Acalymma vittatum (Coleoptera: Chrysomelidae). Environ Entomol 29(3):542-550. https://doi.org/ 10.1603/0046-225X-29.3.542

Gould F, Massey A (1984) Cucurbitacins and predation of the spotted cucumber beetle, Diabrotica undecimpunctata howardi. Entomol Exp Appl 36:273-278. https://doi.org/10.1111/j.1570-7458.1984. tb03439.x

Grunseich JM, Thompson MN, Hay AA, Gorman Z, Kolomiets MV, Eubanks MD, Helms AM (2020) Risky roots and careful herbivores: sustained herbivory by a root-feeding herbivore attenuates indirect plant defences. Funct Ecol 34:1779-1789. https://doi.org/ $10.1111 / 1365-2435.13627$

Hanh TTM, Sharma SK, Rana MK (2014) Pollination efficiency of native bee pollinators of cucumber (Cucumis sativus L.) in India. 
J Apicult 29:199-205. https://doi.org/10.17519/apiculture.2014. 09.29.3.199

He J, Bouwmeester HJ, Dicke M, Kappers IF (2020) Transcriptional and metabolite analysis reveal a shift in direct and indirect defences in response to spider-mite infestation in cucumber (Cucumis sativus). Plant Mol Biol 103(4-5):489-505. https://doi. org/10.1007/s11103-020-01005-y

Helms AM, Ray S, Matulis NL, Kuzemchak MC, Grisales W, Tooker JF, Ali JG (2019) Chemical cues linked to risk: cues from below-ground natural enemies enhance plant defences and influence herbivore behaviour and performance. Funct Ecol 33:798-808. https://doi.org/10.1111/1365-2435.13297

Houser JS, Balduf WV (1925) The striped cucumber beetle: Diabrotica vittata Fabr. Bulletin: Ohio Agricultural Experiment Station

Howe WL, Zdarkova E, Rhodes AM (1972) Host preferences of Acalymma vittatum (Coleoptera: Chrysomelidae) among certain Cucurbitaceae. Ann Entomol Soc Am 65:372-374. https://doi. org/10.1093/aesa/65.2.372

Huang S, Li R, Zhang Z et al (2009) The genome of the cucumber, Cucumis sativus L. Nat Genet 41:1275-1281. https://doi.org/ 10.1038/ng.475

Jeffrey C (1980) A review of the Cucurbitaceae. Bot J Linn Soc 81:233-247. https://doi.org/10.1111/j.1095-8339.1980.tb016 $76 . \mathrm{x}$

Kappers IF, Hoogerbrugge H, Bouwmeester HJ et al (2011) Variation in herbivory-induced volatiles among cucumber (Cucumis sativus L.) varieties has consequences for the attraction of carnivorous natural enemies. J Chem Ecol 37:150-160. https://doi. org/10.1007/s10886-011-9906-7

Kessler A, Baldwin IT (2001) Defensive function of herbivoreinduced plant volatile emissions in nature. Science 291:21412144. https://doi.org/10.1126/science.291.5511.2141

Lewis PA, Lampman RL, Metcalf RL (1990) Kairomonal attractants for Acalymma vittatum (Coleoptera: Chrysomelidae). Environ Entomol 19:8-14. https://doi.org/10.1093/ee/19.1.8

Liu Z, Li Y, Cao C, Liang S, Ma Y, Liu X, Pei Y (2019) The role of $\mathrm{H} 2 \mathrm{~S}$ in low temperature-induced cucurbitacin $\mathrm{C}$ increases in cucumber. Plant Mol Biol 99:535-544. https://doi.org/10.1007/ s11103-019-00834-w

Mallinger RE, Hogg DB, Gratton C (2011) Methyl salicylate attracts natural enemies and reduces populations of soybean aphids (Hemiptera: Aphididae) in soybean agroecosystems. J Econ Entomol 104:115-124. https://doi.org/10.1603/EC10253

McGregor SE (1976) Insect pollination of cultivated crop plants. Agricultural Research Service, U.S. Department of Agriculture

Metcalf RL (1986) Coevolutionary adaptations of rootworm beetles (Coleoptera: Chrysomelidae) to cucurbitacins. J Chem Ecol 12:1109-1124. https://doi.org/10.1007/BF01638999

Metcalf RL, Lampman RL (1989) The chemical ecology of diabroticites and cucurbitaceae. Experientia 45:240-247. https://doi. org/10.1007/BF01951810

Metcalf RL, Metcalf RA, Rhodes AM (1980) Cucurbitacins as kairomones for diabroticite beetles. Proc Natl Acad Sci 77:37693772. https://doi.org/10.1073/pnas.77.7.3769

Metcalf RL, Lampman RL, Deem-Dickson L (1995) Indole as an olfactory synergist for volatile kairomones for diabroticite beetles. J Chem Ecol 21:1149-1162. https://doi.org/10.1007/BF022 28317

Milan NF, Kacsoh BZ, Schlenke TA (2012) Alcohol consumption as self-medication against blood-borne parasites in the fruit fly. Curr Biol 22(6):488-493. https://doi.org/10.1016/j.cub.2012.01.045

Mondal B, Mondal CK, Mondal P (2020) Insect pests and non-insect pests of cucurbits. In: Stresses of cucurbits: current status and management, Chap 3. pp 47-113. https://doi.org/10.1007/ 978-981-15-7891-5_2
Morris BD, Smyth RR, Foster SP, Hoffmann MP, Roelofs WL, Franke $S$, Francke W (2005) Vittatalactone, a $\beta$-Lactone from the striped cucumber beetle, Acalymma vittatum. J Nat Prod 68:26-30. https://doi.org/10.1021/np049751v

Povey S, Cotter SC, Simpson SJ, Wilson K (2014) Dynamics of macronutrient self-medication and illness-induced anorexia in virally infected insects. J Anim Ecol 83(1):245-255. https://doi.org/10. $1111 / 1365-2656.12127$

Qi J, Liu X et al (2013) A genomic variation map provides insights into the genetic basis of cucumber domestication and diversity. Nat Genet 45:1510-1519. https://doi.org/10.1038/ng.2801

Raguso RA (2016) More lessons from linalool: Insights gained from a ubiquitous floral volatile. Curr Opin Plant Biol 32:31-36. https:// doi.org/10.1016/j.pbi.2016.05.007

Raguso RA, Agrawal AA, Douglas AE, Jander G, Kessler A, Poveda K, Thaler JS (2015) The raison d'être of chemical ecology. Ecology 96:617-630. https://doi.org/10.1890/14-1474.1

Rojas ES, Batzer JC, Beattie GA, Fleischer SJ, Shapiro LR, Williams MA, Bessin R, Bruton BD, Boucher TJ, Jesse LCH, Gleason ML (2015) Bacterial wilt of cucurbits: resurrecting a classic pathosystem. Plant Dis 99(5):564-574. https://doi.org/10.1094/ PDIS-10-14-1068-FE

Röse US, Lewis WJ, Tumlinson JH (1998) Specificity of systemically released cotton volatiles as attractants for specialist and generalist parasitic wasps. J Chem Ecol 24:303-319. https://doi.org/10. 1023/A:1022584409323

Schmidt R, Ulanova D, Wick LY, Bode HB, Garbeva P (2019) Microbe-driven chemical ecology: past, present and future. ISME J 13:2656-2663. https://doi.org/10.1038/s41396-019-0469-x

Shang Y, Ma Y, Zhou Y, Zhang H, Duan L, Chen H, Zeng J, Zhou Q, Wang S, Gu W, Liu M, Ren J, Gu X, Zhang S, Wang Y, Yasukawa K, Bouwmeester HJ, Qi X, Zhang Z, Huang S (2014) Biosynthesis, regulation, and domestication of bitterness in cucumber. Science 346:1084-1088. https://doi.org/10.1126/science.1259215

Shapiro L, Moraes CMD, Stephenson AG, Mescher MC (2012) Pathogen effects on vegetative and floral odours mediate vector attraction and host exposure in a complex pathosystem. Ecol Lett 15:1430-1438. https://doi.org/10.1111/ele.12001

Singer MS, Mace KC, Bernays EA (2009) Self-medication as adaptive plasticity: increased ingestion of plant toxins by parasitized caterpillars. PLoS ONE 4(3):e4796. https://doi.org/10.1371/journ al.pone. 0004796

Smyth RR, Hoffmann MP (2003) A male-produced aggregation pheromone facilitating Acalymma vittatum [F.] (Coleoptera: Chrysomelidae) early-season host plant colonization. J Insect Behav 16:347-359. https://doi.org/10.1023/A:1024824025210

Smyth RR, Hoffmann MP (2010) Seasonal incidence of two co-occurring adult parasitoids of Acalymma vittatum in New York State: Centistes (Syrrhizus) diabroticae and Celatoria setosa. Biocontrol 55:219-228. https://doi.org/10.1007/s10526-009-9232-y

Smyth RR, Tallamy DW, Renwick JAA, Hoffmann MP (2002) Effects of age, sex, and dietary history on response to cucurbitacin in Acalymma vittatum. Entomol Exp Appl 104:69-78. https://doi. org/10.1046/j.1570-7458.2002.00992.x

Stanghellini MS, Ambrose JT, Schultheis JR (2002a) Diurnal activity, floral visitation and pollen deposition by honey bees and bumblebees on field-grown cucumber and watermelon. J Apic Res 41:27-34. https://doi.org/10.1080/00218839.2002.11101065

Stanghellini MS, Schultheis JR, Ambrose JT (2002b) Pollen mobilization in selected Cucurbitaceae and the putative effects of pollinator abundance on pollen depletion rates. J Am Soc Hortic Sci 127:29-736. https://doi.org/10.1080/00218839.2002.11101065

Stoewsand GS, Jaworski A, Shannon S, Robinson RW (1985) Toxicologic response in mice fed Cucurbita fruit. J Food Prot 48:50-51. https://doi.org/10.4315/0362-028X-48.1.50 
Takabayashi J, Dicke M, Takahashi S, Posthumus MA, Van Beek TA (1994a) Leaf age affects composition of herbivore-induced synomones and attraction of predatory mites. J Chem Ecol 20:373386. https://doi.org/10.1007/BF02064444

Takabayashi J, Dicke M, Posthumus MA (1994b) Volatile herbivoreinduced terpenoids in plant-mite interactions: variation caused by biotic and abiotic factors. J Chem Ecol 20:1329-1354. https://doi. org/10.1007/BF02059811

Tallamy DW, Gorski PM (1997) Long- and short-term effect of cucurbitacin consumption on Acalymma vittatum (Coleoptera: Chrysomelidae) fitness. Environ Entomol 26:672-677. https:// doi.org/10.1093/ee/26.3.672

Tallamy DW, Stull J, Ehresman NP, Gorski PM, Mason CE (1997) Cucurbitacins as feeding and oviposition deterrents to insects. Environ Entomol 26:678-683. https://doi.org/10.1093/ee/26.3.678

Tallamy DW, Gorski PM, Burzon JK (2000) Fate of male-derived Cucurbitacins in spotted Cucumber beetle females. J Chem Ecol 26:413-427. https://doi.org/10.1023/A:1005461522609

Thaler JS (1999) Jasmonate-inducible plant defences cause increased parasitism of herbivores. Nature 399(6737):686-688. https://doi. org/10.1038/21420

Theis N, Adler LS (2012) Advertising to the enemy: enhanced floral fragrance increases beetle attraction and reduces plant reproduction. Ecology 93:430-435. https://doi.org/10.1890/11-0825.1

Theis N, Kesler K, Adler LS (2009) Leaf herbivory increases floral fragrance in male but not female Cucurbita pepo subsp. Texana (Cucurbitaceae) flowers. Am J Bot 96:897-903. https://doi.org/ 10.3732/ajb.0800300
Theis N, Barber NA, Gillespie SD, Hazzard RV, Adler LS (2014) Attracting mutualists and antagonists: plant trait variation explains the distribution of specialist floral herbivores and pollinators on crops and wild gourds. Am J Bot 101:1314-1322. https://doi.org/ 10.3732/ajb.1400171

Turlings TCJ, Erb M (2018) Tritrophic interactions mediated by herbivore-induced plant volatiles: mechanisms, ecological relevance, and application potential. Annu Rev Entomol 63(1):433-452. https://doi.org/10.1146/annurev-ento-020117-043507

Walton WR (1914) A new tachinid parasite of Diabrotica vittata. Proceedings of the Entomological Society of Washington

Wei G, Tian P, Zhang F, Qin H, Miao H, Chen Q, Hu Z, Cao L, Wang M, Gu X, Huang S, Chen M, Wang G (2016) Integrative analyses of nontargeted volatile profiling and transcriptome data provide molecular insight into VOC diversity in Cucumber plants (Cucumis sativus). Plant Physiol 172(1):603-618. https://doi.org/ 10.1104/pp.16.01051

Yi H-S, Heil M, Adame-Álvarez RM, Ballhorn DJ, Ryu C-M (2009) Airborne induction and priming of plant defenses against a bacterial pathogen. Plant Physiol 151(4):2152-2161. https://doi.org/10. 1104/pp.109.144782

Publisher's Note Springer Nature remains neutral with regard to jurisdictional claims in published maps and institutional affiliations. 